\title{
PERSEPSI PETANI KAKAO TERHADAP TEKNIK SAMBUNG SAMPING DI DESA BATU LAPPA, SULAWESI SELATAN
}

\section{Cocoa Farmers Perception Toward Side-Grafting Technique in Batu Lappa Village, South Sulawesi}

\section{Galib Suwito Cora, Didi Rukmana*, A. Amrullah}

Program Studi Agribisnis, Departemen Sosial Ekonomi Pertanian, Fakultas Pertanian, Universitas Hasanuddin, Makassar

*Kontak penulis: drukmana@unhas.ac.id

\begin{abstract}
The research was aimed to: (1) describe factors that affected farmers' perception toward side-grafting technique; (2) to analyze the level of cacao farmers' perception toward side-grafting technique which include technique and results of side-grafting, (3) to analyze the relationship among factors of perception formulation with technique and results of side-grafting. The research was used quatitative methods. The data was collected by quetionnaire. The research showed that; (1) factors that formed perception include age, formal education, non-formal education, farming experience, accessibility on information, and social environment, (2) the level of farmer's perception toward side-grafting technique was very good with score 4,48 and toward results of side-grafting also was very good with score 4,23 ; (3) it was showed that there were relationship among non-formal education, accessibility on information with farmer's percepcion toward side-grafting technique. Also, there were relationsip among non-formal education toward results of side-grafting.
\end{abstract}

Keywords: perception; cacoa farmer; side-grafting; step of side-grafting; results of side-grafting

Sitasi: Cora, G. S., D. Rukmana, A. Amrullah, 2018. Persepsi Petani Kakao Terhadap Teknik Sambung Samping di Desa Batu Lappa Sulawesi Selatan, JSEP 14(1): 15 - 30.

\section{Pendahuluan}

Kakao merupakan salah satu komoditas andalan perkebunan yang peranannya cukup penting bagi perekonomian nasional dan komoditas perkebunan yang memiliki peranan cukup nyata dan dapat diandalkan dalam mewujudkan program pembangunan pertanian, khususnya dalam hal penyediaan lapangan kerja, pendorong pengembangan wilayah, pengembangan agroindustri, peningkatan kesejahteraan petani, dan peningkatan pendapatan devisa negara (Firdaus, 2015).

Pada usaha budidaya tanaman kakao rakyat, seringkali ditemukan tanaman kakao yang memiliki produksi rendah. Adanya tanaman yang demikian umumnya disebabkan oleh penggunaan bibit asalan yang diperoleh dari sumber bibit yang tidak jelas asal-usulnya. Jika dibiarkan terus tumbuh tanaman dengan produksi rendah ini akan sangat merugikan. Sedangkan bila dibongkar dan diganti dengan tanaman baru (replanting), waktu yang dibutuhkan untuk menunggu tanaman mulai berbuah kembali cukup lama. 
Beberapa faktor yang menyebabkan rendahnya produktivitas kakao selain serangan hama dan penyakit, anomali iklim, tajuk tanaman rusak, populasi tanaman berkurang, teknologi budidaya oleh petani yang masih sederhana, penggunaan bahan tanam yang mutunya kurang baik juga karena umur tanaman yang sudah cukup tua sehingga kurang produktif lagi (Suhendi, 2007; Manubelu, 2011).

Rendahnya produksi kakao disebabkan oleh umur tanaman yang sudah tua memerlukan upaya rehabilitasi dan bila tidak ada upaya tersebut maka kakao menunju proses kehancuran (Salman, 2016). Salah satu cara untuk itu adalah melalui teknik sambung samping. Teknik sambung samping pada tanaman kakao merupakan salah satu teknik peremajaan tanaman kakao yang sudah berumur lanjut ( \pm 18 tahun). Teknik ini menggunakan batang atas (entris) dari kakao klon unggul yang kemudian disambungkan pada batang tanaman kakao dengan tujuan untuk menghasilkan tanaman baru yang lebih produktif (Nai, 2013). Ini merupakan inovasi dalam menjawab kemunduran yang dialami perkebunan kakao, sekaligus mempertemukan pengetahuan lokal petani dengan pengetahuan yang dihantarkan dari luar oleh pemerintah (Husna, et al, 2015; Fahmid, 2013).

Teknik sambung samping merupakan teknik perbanyakan tanaman secara vegetatif dengan menggabungkan bagian dari satu tanaman ke tanaman lain yang sejenis (satu famili) sehingga tumbuh menjadi satu tanaman dan mempunyai sifat yang sama dengan induknya (entrisnya). Hasil penelitian menunjukkan bahwa sambung samping dapat berproduksi pada umur 9 - 12 bulan sesudah perlakuan (Firdaus, 2015). Sambung samping sebaiknya dilakukan pada awal musim hujan, agar tunas yang tumbuh dari sambungan dapat tumbuh dengan cepat. Keuntungan teknologi sambung samping tanaman kakao adalah lebih mudah pelaksanaannya, sehingga areal pertanaman kakao dapat direhabilitasi dalam waktu singkat, dan tanaman kakao lebih cepat berproduksi. Sementara batang atas belum berproduksi, hasil buah dari batang bawah masih dapat dipertahankan, batang bawah dapat berfungsi sebagai penaung sementara bagi batang atas yang sedang tumbuh (Firdaus, 2015).

Di Kecamatan Larompong Selatan, sambung samping tanaman kakao dimulai sejak tahun 2009, sambung samping dilakukan pada tanaman kakao yang kurang produktif (berumur \pm 17 tahun), setelah penyambungan tanaman kakao, membutuhkan waktu ( \pm dua tahun) untuk berproduksi. Keterlibatan petani dalam sambung samping tersebut lahir dari persepsi mereka terhadap sambung samping itu sendiri, berhubung teknik sambung samping ini merupakan inovasi yang dihantarkan dari luar (Salman, 2016).

Secara agronomis, kakao memiliki taksonomi yang terdiri dari divisi: Spermatophyta, sub-divisi: Angiospermae, kelas: Dicotyledoneae, sub kelas: Dialypetalae, bangsa: Malvales, suku: Sterculiaceae, marga: theobroma, jenis: Theobroma cacao L. Dari 22 jenis yang ada dalam marga Theobroma (suku Sterculiaceae), Theobroma cacao diklaim sebagai satu-satunya jenis yang telah diusahakan secara komersial dan paling populer untuk dipasarkan (Prawoto et-al, 2008).

Dalam perkembangan kakao di Sulawesi Selatan, telah terjadi kemunduran karena umur tanaman yang semakin tua seiring dengan munculnya berbagai serangan penyakit. Untuk mengatasi kemunduran tersebut salah satu upaya yang ditempuh pemerintah bersama masyarakat tani adalah rehabilitasi tanaman melalui sambung samping. Sambung samping ini dihantarkan sebagai inovasi oleh 
pemerintah maupun oleh berbagai perusahaan yang bergerak pada industri dan perdagangan kakao. Keberhasilan implementasi teknik ini amat bergantung pada persepsi petani terhadapnya.

Persepsi merupakan penilaian atau pandangan individu terhadap suatu objek. Individu menyeleksi, mengatur dan menginterpretasikan masukan-masukan informasi dan pengalaman-pengalaman yang ada, dan kemudian menafsirkannya untuk menciptakan keseluruhan gambaran yang berarti. Persepsi penting untuk diteliti karena dengan adanya persepsi, maka individu dapat menyadari dan mengerti tentang keadaan lingkungan di sekitarnya, dan dapat pula mempengaruhi individu dalam mengambil sebuah keputusan (Damayanti, 2010). Dihubungkan dengan berkembangnya teknik sambung samping sebagai inovasi dalam mengatasi kemunduran produksi kakao, persepsi petani terkait dengan tahapan-tahapan dari teknik sambung samping dan hasil dari sambung samping itu sendiri. Persepsi ini terbentuk melalui faktor-faktor pembentuk persepsi, yang dalam konteks petani pembentuk persepsi petani tersebut dapat berasal dari dalam diri petani meliputi umur, pendidikan formal, pendidikan non formal, pengalaman berusahatani, maupun dari luar diri petani yang mencakup aksesibilitas terhadap informasi dan lingkungan sosial (Novitasari, 2013).

Penelitian ini bertujuan untuk: (1) Mendeskripsikan faktor-faktor pembentuk persepsi petani kakao terhadap teknik sambung samping; (2) Menganalisis tingkat persepsi petani kakao terhadap teknik sambung samping yang meliputi tahapan teknik sambung samping dan hasil teknik sambung samping; (3) Menganalisis hubungan faktor-faktor pembentuk persepsi dengan persepsi petani kakao terhadap teknik sambung samping.

\section{Metode Penelitian}

Penelitian dilaksanakan di Desa Batu Lappa, Kecamatan Larompong Selatan, Kabupaten Luwu, Provinsi Sulawesi Selatan. Penentuan lokasi penelitian dilakukan secara sengaja (purposive), dengan pertimbangan bahwa lokasi penelitian merupakan salah satu sentra komoditas kakao di Kabupaten Luwu dan petani kakao yang ada di lokasi telah melakukan rehabilitasi tanaman kakao dengan menggunakan teknik sambung samping.

Populasi penelitian ini adalah semua petani kakao sambung samping yang tergabung dalam kelompoktani di lokasi penelitian yang berjumlah 321 orang. Penarikan sampel dari populasi dilakukan secara proportionate stratified random sampling sebanyak 10\%, sehingga jumlah sampel yang dipilih sebanyak 32 orang. Penarikan sampel ini dilakukan dengan pertimbangan apabila subjek kurang 100 lebih baik populasi diambil semua sebagai sampel, tetapi kalau lebih dari 100 maka dapat diambil 10 - 15\% atau 20 - 25\% (Arikunto, 2010). Penarikan sampel secara proportionate stratified random sampling menggunakan rumus:

$$
\mathrm{ni}=\frac{\mathrm{Ni}}{\mathrm{N}} \mathrm{Xn}
$$

Keterangan:

ni : jumlah anggota sampel menurut stratum

$\mathrm{Ni}$ : jumlah anggota populasi menurut stratum

$\mathrm{N} \quad$ : jumlah anggota populasi seluruhnya

$\mathrm{n} \quad$ : ukuran sampel 
Data yang dikumpulkan pada penelitian ini terdiri dari data primer dan data sekunder. Data primer diperoleh dari hasil wawancara langsung dengan responden penelitian dan melalui daftar kuisioner yang telah dipersiapkan terlebih dahulu. Data sekunder diperoleh dari lembaga atau instansi yang terkait dengan penelitian ini, seperti Badan Pusat Statistik, Dinas Perkebunan dan literatur-literatur yang berhubungan dengan penelitian.

Data yang diperoleh selanjutnya dianalisis untuk mencapai tujuan penelitian. Faktor-faktor pembentuk persepsi petani kakao terhadap teknik sambung samping dianalisis dengan menggunakan tabel frekuensi. Untuk mengetahui tingkat persepsi petani kakao terhadap teknik sambung samping dianalisis dengan menggunakan rumus:

$$
\mathrm{Rs}=\frac{\sum(\mathrm{n} \times \mathrm{s})}{\mathrm{N}}
$$

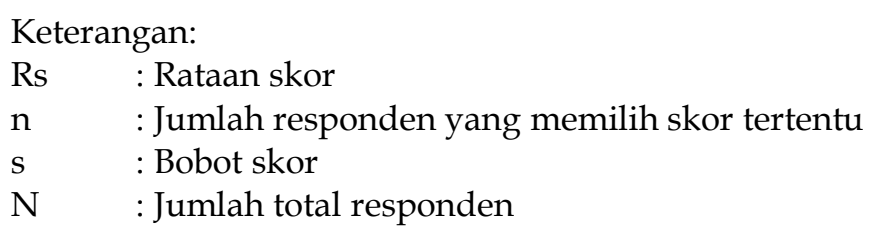

Dengan interpretasi selanjutnya adalah memberi penilaian terhadap masing-masing kriteria yang dinilai dalam kuisioner, sehingga diperoleh kesimpulan bagaimana tanggapan responden terhadap variabel-variabel yang diteliti, dengan menggunakan rumus:

Keterangan:

$$
\mathrm{RK}=\frac{\mathrm{m}-\mathrm{n}}{\mathrm{K}}
$$

RK : Rentang kriteria

M : Skala jawaban terbesar

$\mathrm{N} \quad$ : Skala jawaban terkecil

K : Jumlah kelas

Berdasarkan rumus ini, maka dapat diperoleh rentang kriteria, sebagai berikut:

$$
\mathrm{RK}=\frac{5-1}{5}=0.8
$$

Sehingga dapat disusun indeks dan kriteria penilaian sebagaimana yang diuraikan pada Tabel 1.

Tabel 1

Indeks dan Kriteria Penilaian

\begin{tabular}{ccl}
\hline No. & Indeks Penilaian & Kriteria \\
\hline 1 & $1.00-1.80$ & Sangat Buruk \\
2 & $1.81-2.60$ & Buruk \\
3 & $2.61-3.40$ & Sedang \\
4 & $3.41-4.20$ & Baik \\
5 & $4.21-5.00$ & Sangat Baik \\
\hline
\end{tabular}

Selanjutnya, hubungan faktor-faktor pembentuk persepsi dengan persepsi petani kakao terhadap teknik sambung samping dianalisis dengan menggunakan rumus: 


$$
\mathrm{rs}=1-\frac{6 \sum \mathrm{di}^{2}}{N^{3}-N}
$$

Keterangan:

$$
\begin{array}{ll}
\text { rs } & \text { : Koefisien korelasi rank spearman } \\
\text { di } & \text { : Selisih ranking variabel } \\
\mathrm{N} & \text { : Banyaknya sampel }
\end{array}
$$

Rumus ini dapat dipergunakan jika tidak terdapat data kembar dari data yang diperoleh, namun untuk mengetahui korelasi rank spearman yang terdapat dua subjek atau lebih memperoleh skor yang sama digunakan rumus:

$$
\mathrm{rs}=\frac{\sum \mathrm{x}^{2}+\sum \mathrm{y}^{2}-\sum \mathrm{di}^{2}}{2 \cdot \sqrt{\sum \mathrm{x}^{2} \cdot \sum \mathrm{y}^{2}}}
$$

dimana:

$$
\begin{aligned}
& \sum \mathrm{x}^{2}=\frac{\mathrm{N}^{3}-\mathrm{N}}{12}-\sum \mathrm{Tx} \\
& \sum \mathrm{y}^{2}=\frac{\mathrm{N}^{3}-\mathrm{N}}{12}-\sum \mathrm{Ty}
\end{aligned}
$$

Keterangan:

$$
\begin{array}{ll}
\text { rs } & \text { : Koefisien korelasi rank spearman } \\
\text { di } & \text { : Selisih ranking variabel } \\
\mathrm{N} & \text { : Banyaknya sampel } \\
\mathrm{Tx} & \text { : Faktor korelasi } \mathrm{x} \\
\mathrm{Ty} & \text { : Faktor korelasi y }
\end{array}
$$

Pada perhitungan yang terdapat dua atau lebih subjek yang mendapat skor yang sama pada suatu variabel, maka digunakan rumus:

$$
T=\frac{\mathrm{t}^{3}-\mathrm{t}}{12}
$$

Dimana $\mathrm{T}$ adalah banyaknya observasi yang berangka sama pada suatu rangking tertentu (Sihombing, 2008). Untuk melihat nyata tidaknya hubungan antara variabel di uji dengan menggunakan uji $Z$ dengan rumus:

$$
Z=r s \sqrt{n-1}
$$

Kriteria pengambilan keputusan:

- Jika $Z_{\text {hitung }} \leq \mathrm{Z}_{\text {tabel }}(\alpha=0,05)$, maka $\mathrm{H}_{0}$ diterima dan $\mathrm{H}_{1}$ ditolak, berarti tidak ada hubungan antara faktor-faktor pembentuk persepsi petani kakao dengan persepsi petani kakao terhadap tahapan teknik sambung samping.

- Jika $Z_{\text {hitung }}>Z_{\text {tabel }}(a=0,05)$, maka $\mathrm{H}_{0}$ ditolak dan $\mathrm{H}_{1}$ diterima berarti terdapat hubungan antara faktor-faktor pembentuk persepsi petani kakao dengan persepsi petani kakao terhadap tahapan teknik sambung samping.

\section{Hasil dan Pembahasan}

\section{Faktor-Faktor Pembentuk Persepsi}

Persepsi petani kakao terhadap teknik sambung samping dipengaruhi oleh beberapa faktor. Dalam penelitian ini faktor pembentuk persepsi yang digunakan terdiri dari umur, pendidikan formal, pendidikan non formal, pengalaman berusahatani, aksesibilitas terhadap informasi dan lingkungan sosial. 
Umur

Umur responden sangat beragam, umur yang dimaksud yaitu umur petani responden pada saat penelitian ini dilakukan. Distribusi responden berdasarkan umur dapat dilihat pada Tabel 2.

Tabel 2

Distribusi Responden Berdasarkan Umur di Desa Batu Lappa, Kecamatan Larompong Selatan, Kabupaten Luwu, 2016

\begin{tabular}{|c|c|c|c|}
\hline No. & $\begin{array}{l}\text { Kriteria } \\
\text { (Tahun) }\end{array}$ & $\begin{array}{l}\text { Jumlah } \\
\text { (Orang) }\end{array}$ & $\begin{array}{c}\text { Persentase } \\
(\%)\end{array}$ \\
\hline 1 & $\geq 65$ Tahun & 2 & 6,25 \\
\hline 2 & 54-64 Tahun & 6 & 18,75 \\
\hline 3 & 43-53 Tahun & 9 & 28,13 \\
\hline 4 & 32-42 Tahun & 11 & 34,38 \\
\hline \multirow[t]{2}{*}{5} & $\leq 31$ & 4 & 12,5 \\
\hline & Jumlah & 32 & 100 \\
\hline
\end{tabular}

Data yang disajikan pada Tabel 2 menunjukkan bahwa mayoritas (34,38\%) umur responden berada dalam kisaran 32 - 42 tahun. Jika dikelompokkan dalam kategori umur produktif dan non produktif, sebagian besar berada pada umur produktif, yaitu sebesar $93.75 \%$, sedangkan responden yang tergolong umur non produktif sebesar 6,25\%. Samadi (2006) mengemukakan bahwa struktur penduduk berdasarkan umur dibagi menjadi tiga kelompok, yaitu: Umur 0 - 14 tahun dinamakan usia muda merupakan kelompok usia belum produktif, Umur 15 - 64 tahun dinamakan usia dewasa merupakan kelompok usia produktif atau usia kerja, serta umur 65 tahun dan lebih dinamakan usia tua merupakan kelompok usia tidak produktif lagi.

\section{Pendidikan Formal}

Pendidikan formal adalah tingkat pendidikan yang ditamatkan responden pada lembaga pendidikan formal atau bangku sekolah. Tingkat pendidikan yang ditempuh seseorang akan memberikan pengetahuan yang lebih baik tentang cara berpikir, penerimaan suatu informasi, maupun penilaian terhadap suatu masalah yang terjadi (Anggraini, 2011). Distribusi responden berdasarkan tingkat pendidikan formal dapat dilihat pada Tabel 3.

Tabel 3

Distribusi Responden Berdasarkan Tingkat Pendidikan Formal

di Desa Batu Lappa, Kecamatan Larompong Selatan, Kabupaten Luwu, 2016

\begin{tabular}{clcc}
\hline No. & \multicolumn{1}{c}{ Kriteria } & $\begin{array}{c}\text { Jumlah } \\
\text { (Orang) }\end{array}$ & $\begin{array}{c}\text { Persentase } \\
\mathbf{( \% )}\end{array}$ \\
\hline 1 & Tidak Tamat SD & 2 & 6,25 \\
2 & SD & 19 & 59,38 \\
3 & SMP & 8 & 25,00 \\
4 & SMA/SMK & 3 & 9,38 \\
5 & Perguruan Tinggi (D3, S1, S2,S3) & - & - \\
\hline & Jumlah & $\mathbf{3 2}$ & $\mathbf{1 0 0 , 0 0}$ \\
\hline
\end{tabular}


Tabel 3 memperlihatkan data yang menunjukkan bahwa mayoritas tingkat pendidikan formal responden adalah tingkat SD yang berjumlah sebanyak 19 orang $(59,38 \%)$, sedangkan tingkat pendidikan formal dengan jumlah responden yang paling sedikit adalah pada tingkat tidak tamat SD sebanyak dua orang $(6,25 \%)$.

\section{Pendidikan Non Formal}

Pendidikan non formal merupakan aktifitas memperoleh pengetahuan dan keterampilan yang diperoleh petani kakao responden di luar pendidikan formal yang pernah dilaluinya, dalam hal ini keikutsertaan dalam kegiatan penyuluhan dan pelatihan penyambungan yang pernah dilakukan di lokasi penelitian. Distribusi dan tingkat pendidikan non formal responden berdasarkan keikutsertaan pada saat penyuluhan dan pelatihan penyambungan dapat dilihat pada Tabel 4.

\section{Tabel 4}

Distribusi dan Tingkat Pendidikan Non Formal Responden

Berdasarkan Keikutsertaan pada saat Penyuluhan dan Pelatihan Penyambungan di Desa Batu Lappa, Kecamatan Larompong Selatan, Kabupaten Luwu, 2016

\begin{tabular}{clccc}
\hline No. & \multicolumn{1}{c}{ Kriteria } & Skor & $\begin{array}{c}\text { Jumlah } \\
\text { (Orang) }\end{array}$ & $\begin{array}{c}\text { Persentase } \\
\mathbf{( \% )}\end{array}$ \\
\hline 1 & Tidak Ikut Serta & 1 & - & - \\
2 & Ikut Serta Penyuluhan & 2 & - & - \\
3 & Ikut Serta Pelatihan & 3 & - & - \\
4 & Ikut Serta pada Penyuluhan dan Pelatihan & 4 & 5 & $\mathbf{1 5 , 6 3}$ \\
5 & $\begin{array}{l}\text { Ikut Serta dan Aktif pada Penyuluhan dan } \\
\text { Pelatihan }\end{array}$ & 5 & 27 & 84,37 \\
\hline & & Jumlah & $\mathbf{3 2}$ & $\mathbf{1 0 0 , 0 0}$ \\
\hline
\end{tabular}

Berdasarkan data yang disajikan pada Tabel 4, maka dapat diketahui bahwa mayoritas atau sebanyak 27 orang $(84,37 \%)$ responden telah pernah ikut serta dan aktif pada kegiatan penyuluhan dan pelatihan penyambungan yang pernah dilakukan di lokasi penelitian, selebihnya terdapat 5 orang $(15,63 \%)$ responden yang pernah ikut pada penyuluhan dan pelatihan penyambungan, meskipun tidak aktif dalam kegiatan tersebut.

\section{Pengalaman Berusahatani}

Pengalaman berusahatani dalam penelitian ini diukur melalui waktu yang telah dilalui oleh petani kakao responden dalam melaksanakan kegiatan berusahatani kakao hingga penelitian dilaksanakan yang dinyatakan dalam tahun. Distribusi responden berdasarkan tingkat pengalaman berusahatani kakao secara rinci dapat dilihat pada Tabel 5. Data tersebut menunjukkan bahwa mayoritas petani kakao responden memiliki pengalaman berusahatani kakao $>20$ tahun dengan jumlah responden 10 orang $(31,25 \%)$, sedangkan responden yang paling sedikit terdapat pada kriteria pengalaman berusahatani antara 11 - 15 tahun dan 16 - 20 tahun yang berjumlah masing-masing sebanyak tujuh orang $(21,88 \%)$. 
Tabel 5

Distribusi dan Tingkat Pengalaman Berusahatani Responden

Berdasarkan Lamanya Berusahatani di Desa Batu Lappa,

Kecamatan Larompong Selatan, Kabupaten Luwu, 2016

\begin{tabular}{cccc}
\hline No. & $\begin{array}{c}\text { Kriteria } \\
\text { (tahun) }\end{array}$ & $\begin{array}{c}\text { Jumlah } \\
\text { (Orang) }\end{array}$ & $\begin{array}{c}\text { Persentase } \\
\mathbf{( \% )}\end{array}$ \\
\hline 1 & $<5$ & - & - \\
2 & $5-10$ & 8 & 25 \\
3 & $11-15$ & 7 & 21,88 \\
4 & $16-20$ & 7 & 21,88 \\
5 & $>20$ & 10 & 31,25 \\
\hline & Jumlah & $\mathbf{3 2}$ & $\mathbf{1 0 0 , 0 0}$ \\
\hline
\end{tabular}

\section{Aksesibilitas Terhadap Informasi}

Aksesibilitas terhadap informasi merupakan pencarian informasi, kemauan mendapatkan informasi dan jumlah sumber informasi yang aktif dimanfaatkan oleh responden terhadap informasi yang berkaitan dengan tanaman kakao. Pencarian informasi yang dimaksud, yaitu frekuensi pencarian informasi yang dilakukan oleh responden dengan mengikuti kegiatan penyuluhan dalam setahun. Tabel 6 menunjukkan distribusi dan tingkat aksesibilitas informasi responden berdasarkan frekuensi pencarian informasi.

Tabel 6

Distribusi dan Tingkat Aksesibilitas Informasi Responden

Berdasarkan Frekuensi Pencarian Informasi di Desa Batu Lappa, Kecamatan Larompong Selatan, Kabupaten Luwu, 2016

\begin{tabular}{clccc}
\hline No & \multicolumn{1}{c}{ Kriteria } & Skor & $\begin{array}{c}\text { Jumlah } \\
\text { (Orang) }\end{array}$ & $\begin{array}{c}\text { Persentase } \\
\text { (\%) }\end{array}$ \\
\hline 1 & Tidak Pernah & 1 & - & - \\
2 & Kadang-kadang & 2 & - & - \\
3 & Cukup & 3 & 4 & 12,50 \\
4 & Sering & 4 & 12 & 37,50 \\
5 & Sangat Sering & 5 & 16 & 50,00 \\
\hline & Jumlah & & $\mathbf{3 2}$ & $\mathbf{1 0 0 , 0 0}$ \\
\hline
\end{tabular}

Seluruh responden pada penelitian ini dalam mengakses informasi berdasarkan frekuensi pencarian informasi berada pada kriteria cukup hingga sangat sering dengan mayoritas responden berada pada kriteria sangat sering, yakni sebanyak 16 responden $(50 \%)$, kriteria sering sebanyak 12 orang $(37,50)$ dan kriteria cukup sebanyak empat responden (12,50\%). Distribusi dan tingkat aksesibilitas informasi responden berdasarkan kemauan mendapatkan informasi dapat dilihat pada Tabel 7. Data pada Tabel 7 menujukkan kemauan responden mencari informasi terkait informasi tanaman kakao, khususnya tanaman kakao sambung samping. Mayoritas kemauan responden mendapatkan informasi terdapat pada kriteria sangat mau dengan jumlah responden 23 orang $(71,87 \%)$, sedangkan responden yang paling sedikit terdapat pada kriteria mau dengan jumlah responden sebanyak sembilan orang $(28,13 \%)$. 
Tabel 7

Distribusi dan Tingkat Aksesibilitas Informasi Responden

Berdasarkan Kemauan Mendapatkan Informasi di Desa Batu Lappa,

Kecamatan Larompong Selatan, Kabupaten Luwu, 2016.

\begin{tabular}{llccc}
\hline No. & \multicolumn{1}{c}{ Kriteria } & Skor & $\begin{array}{c}\text { Jumlah } \\
\text { (Orang) }\end{array}$ & $\begin{array}{c}\text { Persentase } \\
(\mathbf{0})\end{array}$ \\
\hline 1 & Sangat tidak mau & 1 & - & - \\
2 & Tidak mau & 2 & - & - \\
3 & Cukup mau & 3 & - & - \\
4 & Mau & 4 & 9 & 28,13 \\
5 & Sangat mau & 5 & 23 & 71,87 \\
\hline & & Jumlah & $\mathbf{3 2}$ & $\mathbf{1 0 0 , 0 0}$ \\
\hline
\end{tabular}

Distribusi dan tingkat aksesibilitas informasi responden berdasarkan jumlah sumber informasi yang aktif dimanfaatkan sampai pada saat penelitian ini dilakukan diuraikan secara rinci pada Tabel 8.

Tabel 8

Distribusi dan Tingkat Aksesibilitas Informasi Responden Berdasarkan Jumlah Sumber Informasi Yang Aktif Dimanfaatkan Responden di Desa Batu Lappa, Kecamatan Larompong Selatan, Kabupaten Luwu, 2016

\begin{tabular}{clccc}
\hline No. & \multicolumn{1}{c}{ Kriteria } & Skor & $\begin{array}{c}\text { Jumlah } \\
\text { (Orang) }\end{array}$ & $\begin{array}{c}\text { Persentase } \\
\text { (\%) }\end{array}$ \\
\hline 1 & Tidak Pernah & 1 & - & - \\
2 & 1-2 Sumber informasi & 2 & 5 & 15,63 \\
3 & 3-4 Sumber informasi & 3 & 27 & 84,38 \\
4 & 5-6 Sumber informasi & 4 & - & - \\
5 & > 6 Sumber informasi & 5 & - & - \\
\hline Jumlah & & $\mathbf{3 2}$ & $\mathbf{1 0 0 , 0 0}$ \\
\hline
\end{tabular}

Tabel 8 menunjukkan bahwa sebagian besar responden pada penelitian ini memanfaatkan 3 - 4 sumber informasi, yakni sebanyak 27 orang $(84,38 \%)$, sedangkan responden yang paling sedikit terdapat pada kriteria memanfaatkan 1 - 2 sumber informasi dengan jumlah responden lima orang (15,63\%). Sumber informasi yang paling banyak dimanfaatkan oleh petani adalah tenaga penyuluh.

\section{Lingkungan Sosial}

Lingkungan sosial merupakan lingkungan sosial masyarakat di sekitar responden yang keberadaannya mendorong responden dalam mengenal tanaman kakao sambung samping dengan memberikan informasi kepada responden mengenai adanya inovasi dalam hal ini sambung samping tanaman kakao. Tabel 9 menunjukkan distribusi responden berdasarkan lingkungan sosial pemberi informasi kepada responden. responden yang menganggap 3 - 4 elemen masyarakat pemberi informasi kepada responden untuk mengenal tanaman kakao sambung 
samping lebih banyak yaitu berjumlah 20 responden $(62,50 \%)$, sedangkan responden yang menganggap 5 - 6 elemen masyarakat pemberi informasi kepada responden untuk mengenal tanaman kakao sambung samping lebih sedikit yaitu berjumlah 12 responden $(37,50 \%)$.

\section{Tabel 9}

Distribusi Responden Berdasarkan Lingkungan Sosial Pemberi Informasi kepada Responden di Desa Batu Lappa, Kecamatan Larompong Selatan, Kabupaten Luwu 2016

\begin{tabular}{ccccc}
\hline No. & Kriteria & Skor & $\begin{array}{c}\text { Jumlah } \\
\text { (Orang) }\end{array}$ & $\begin{array}{c}\text { Persentase } \\
\text { (\%) }\end{array}$ \\
\hline 1 & Tidak ada yang memberi informasi & 1 & - & - \\
2 & 1-2 Elemen masyarakat & 2 & - & - \\
3 & 3-4 Elemen masyarakat & 3 & 20 & 62,50 \\
4 & 5-6 Elemen masyarakat & 4 & 12 & 37,50 \\
5 & > 6 Elemen masyarakat & 5 & - & - \\
\hline & & Jumlah & $\mathbf{3 2}$ & $\mathbf{1 0 0 , 0 0}$ \\
\hline
\end{tabular}

\section{Persepsi Terhadap Teknik Sambung Samping}

Persepsi total petani terhadap tahapan teknik sambung samping meliputi penyiapan batang bawah, penyayatan batang bawah, penyiapan entres, penyisipan entres, ketinggian sambungan, penyungkupan entres, pengamatan sambungan, serta pemeliharaan sambungan. Persepsi total petani responden terhadap tahapan teknik sambung samping secara keseluruhan berada pada kategori sangat baik dengan skor 4,48. Skor dan kategori ini menunjukkan bahwa responden memiliki pemahaman yang sangat baik dalam melakukan sambung samping tanaman kakao. Untuk lebih jelasnya mengenai persepsi petani kakao terhadap tahapan teknik sambung samping tanaman kakao dapat dilihat pada Tabel 10.

Tabel 10

Persepsi Total Petani Kakao Terhadap Tahapan Teknik Sambung Samping di Desa Batu Lappa, Kecamatan Larompong Selatan, Kabupaten Luwu, 2016

\begin{tabular}{|c|c|c|c|c|c|}
\hline No. & Variabel & $\begin{array}{l}\text { Skor Total } \\
\text { (a) }\end{array}$ & $\begin{array}{c}\sum \text { Pertanyaan } \\
\text { (b) }\end{array}$ & $\begin{array}{l}\text { Skor } \\
(\mathrm{a} / \mathrm{b})\end{array}$ & Kategori \\
\hline 1 & Penyiapan batang bawah & 18,14 & 4 & 4,54 & Sangat Baik \\
\hline 2 & Pengayatan batang bawah & 14,31 & 3 & 4,77 & Sangat Baik \\
\hline 3 & Penyiapan entres & 12,88 & 3 & 4,29 & Sangat Baik \\
\hline 4 & Penyisipan entres & 14,29 & 3 & 4,76 & Sangat Baik \\
\hline 5 & Ketinggian sambungan & 9,10 & 2 & 4,55 & Sangat Baik \\
\hline 6 & Penyungkupan entres & 8,60 & 2 & 4,30 & Sangat Baik \\
\hline 7 & Pengamatan sambungan & 22,07 & 5 & 4,41 & Sangat Baik \\
\hline \multirow[t]{2}{*}{8} & Pemeliharaan sambungan & 17,13 & 4 & 4,28 & Sangat Baik \\
\hline & Jumah & 116,52 & 26 & 4,48 & Sangat Baik \\
\hline Keterangan: & $\begin{array}{l}\text { 1,00 - 1,80 (Sangat bur } \\
2,61-3,40 \text { (Sedang) }\end{array}$ & $\begin{array}{l}1,81 \\
3,41\end{array}$ & $\begin{array}{l}60 \text { (Buruk) } \\
20 \text { (Baik) }\end{array}$ & 5,00 & gat baik) \\
\hline
\end{tabular}




\section{Persepsi Terhadap Hasil Teknik Sambung Samping}

Persepsi petani terhadap hasil teknik sambung samping merupakan penilaian dan pendapat petani mengenai hasil sambung samping yang meliputi produksi tanaman kakao, kualitas tanaman kakao, keuntungan usahatani tanaman kakao. Persepsi total responden terhadap hasil teknik sambung samping merupakan total penilaian dan pendapat responden mengenai produksi tanaman kakao sambung samping, kualitas tanaman kakao sambung samping, serta keuntungan usahatani tanaman kakao sambung samping. Persepsi total responden terhadap hasil teknik sambung samping dapat dilihat pada Tabel 11.

Tabel 11

Persepsi Total Petani Kakao Terhadap Hasil Teknik Sambung Samping di Desa Batu Lappa, Kecamatan Larompong Selatan, Kabupaten Luwu 2016

\begin{tabular}{|c|c|c|c|c|c|c|}
\hline No & \multicolumn{2}{|r|}{ Variabel } & \multirow{2}{*}{$\begin{array}{c}\begin{array}{c}\text { Skor } \\
\text { Total (a) }\end{array} \\
4.63\end{array}$} & \multirow{2}{*}{$\begin{array}{c}\sum \text { Pertanyaan } \\
\text { (b) }\end{array}$} & \multirow{2}{*}{$\begin{array}{l}\text { Skor } \\
(\mathrm{a} / \mathrm{b})\end{array}$} & \multirow{2}{*}{$\begin{array}{r}\text { Kategori } \\
\text { Sangat Baik }\end{array}$} \\
\hline 1 & Pro & luksi & & & & \\
\hline 2 & Kua & litas tanaman kakao & 7,88 & 2 & 3,94 & Baik \\
\hline \multirow[t]{2}{*}{3} & Keu & ntungan usahatani & 4,41 & 1 & 4,41 & Sangat Baik \\
\hline & & Jumlah & 16,92 & 4 & 4,23 & Sangat Baik \\
\hline Keterar & gan: & $\begin{array}{l}1,00-1,80 \text { (Sangat buruk) } \\
2,61-3,40 \text { (Sedang) } \\
4,21-5,00 \text { (Sangat baik) }\end{array}$ & $\begin{array}{l}1,81- \\
3,41-\end{array}$ & $\begin{array}{l}\text { 2,60 (Buruk) } \\
4,20 \text { (Baik) }\end{array}$ & & \\
\hline
\end{tabular}

Berdasarkan data pada Tabel 11 dapat diketahui bahwa total persepsi petani kakao terhadap hasil teknik sambung samping berada pada kategori sangat baik dengan skor 4,23. Hal ini menunjukkan bahwa responden mempunyai persepsi yang sangat baik terhadap hasil dari teknik sambung samping.

\section{Hubungan Faktor Pembentuk Persepsi dengan Persepsi Petani Kakao Terhadap Tahapan Teknik Sambung Samping}

Faktor pembentuk persepsi petani dapat berasal dari dalam diri sendiri ataupun dari luar diri petani meliputi umur, pendidikan formal, pendidikan non formal, pengalaman berusahatani, aksesibilitas terhadap informasi dan lingkungan sosial. Adapun untuk melihat ada tidaknya hubungan antara faktor pembentuk persepsi dengan persepsi petani kakao terhadap tahapan teknik sambung samping dapat dilihat pada penjelasan berikut.

Hubungan Umur dengan Persepsi Petani Kakao Terhadap Tahapan Teknik Sambung Samping

Hasil analisis menunjukkan nilai dari koefisien korelasi Rank Spearmant adalah 0,183. Nilai $Z_{\text {hitung }}$ sebesar 1,019. Berdasarkan tabel Z dengan menggunakan a 0,05 maka diperoleh $Z_{\text {tabel }}$ sebesar 1,96. Dapat dilihat bahwa $Z_{\text {hitung }}<Z_{\text {tabel }}$ dengan demikian $\mathrm{H}_{0}$ diterima dan $\mathrm{H}_{1}$ ditolak, artinya tidak ada hubungan antara umur dengan persepsi petani kakao terhadap tahapan teknik sambung samping. 
Hubungan Pendidikan Formal dengan Persepsi Petani Kakao Terhadap Tahapan Teknik Sambung Samping

Berdasarkan hasil penelitian dapat diketahui bahwa nilai dari koefisien korelasi Rank Spearman adalah -0,272. Nilai Z Zitung sebesar -1,515. Berdasarkan tabel Z dengan menggunakan a 0,05 maka diperoleh $Z_{\text {tabel }}$ sebesar 1,96. Dapat dilihat bahwa Zhitung $<Z_{\text {tabel }}$ dengan demikian $\mathrm{H}_{0}$ diterima dan $\mathrm{H}_{1}$ ditolak, artinya tidak ada hubungan antara pendidikan formal dengan persepsi petani kakao terhadap tahapan teknik sambung samping.

Hubungan Pendidikan Non Formal dengan Persepsi Petani Kakao Terhadap Tahapan Teknik Sambung Samping

Hasil analisis data menunjukkan bahwa nilai dari koefisien korelasi Rank Spearman adalah 0,553. Nilai $Z_{\text {hitung }}$ sebesar 3,080. Berdasarkan tabel Z dengan menggunakan a 0,05 maka diperoleh $Z_{\text {tabel }}$ sebesar 1,96. Dapat dilihat bahwa Zhitung $>$ $Z_{\text {tabel }}$ dengan demikian $\mathrm{H}_{0}$ ditolak dan $\mathrm{H}_{1}$ diterima, artinya ada hubungan antara pendidikan non formal dengan persepsi petani kakao terhadap tahapan teknik sambung samping.

Hubungan Pengalaman Berusahatani dengan Persepsi Petani Kakao Terhadap Tahapan Teknik Sambung Samping

Berdasarkan hasil penelitian dapat diketahui bahwa nilai dari koefisien korelasi

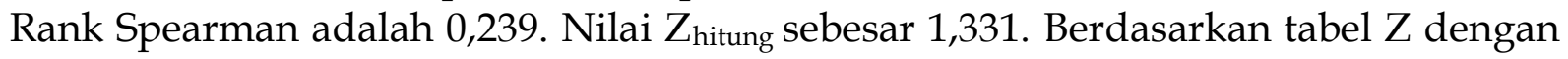

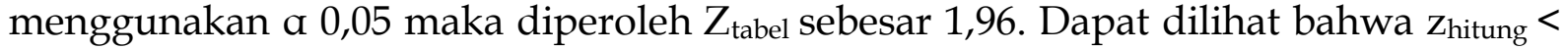
$Z_{\text {tabel }}$ dengan demikian $\mathrm{H}_{0}$ diterima dan $\mathrm{H}_{1}$ ditolak, artinya tidak ada hubungan antara pengalaman berusahatani dengan persepsi petani kakao terhadap tahapan teknik sambung samping.

Hubungan Aksesibilitas Informasi dengan Persepsi Petani Kakao Terhadap Tahapan Teknik Sambung Samping

Aksesibilitas terhadap informasi merupakan pencarian informasi yang dilakukan responden dengan mengikuti kegiatan penyuluhan dalam setahun, kemauan mendapatkan informasi dan jumlah sumber informasi yang aktif dimanfaatkan responden terhadap informasi yang berkaitan dengan tanaman kakao.

Hasil perhitungan hubungan aksesibilitas informasi berdasarkan frekuensi pencarian informasi dengan persepsi petani kakao terhadap tahapan teknik sambung samping diperoleh nilai dari koefisien korelasi Rank Spearman adalah 0,503. Nilai Z hitung sebesar 2,802. Berdasarkan tabel Z dengan menggunakan a 0,05 maka diperoleh $Z_{\text {tabel }}$ sebesar 1,96. Dapat dilihat bahwa $Z$ hitung $>Z_{\text {tabel }}$ dengan demikian $\mathrm{H}_{0}$ ditolak dan $\mathrm{H}_{1}$ diterima, artinya ada hubungan antara frekuensi pencarian infromasi dengan persepsi petani kakao terhadap tahapan teknik sambung samping.

Hubungan aksesibilitas informasi berdasarkan kemauan responden diperoleh informasi bahwa persepsi petani kakao terhadap tahapan teknik sambung dengan nilai dari koefisien korelasi Rank Spearman adalah 0,394. Nilai $Z_{\text {hitung }}$ sebesar 2,195. Berdasarkan tabel $\mathrm{Z}$ dengan menggunakan a 0,05 maka diperoleh $Z_{\text {tabel }}$ sebesar 1,96. Dapat dilihat bahwa Zhitung $>$ ztabel dengan demikian $\mathrm{H}_{0}$ ditolak dan $\mathrm{H}_{1}$ diterima, artinya ada hubungan antara kemauan mendapatkan infromasi dengan persepsi petani kakao terhadap tahapan teknik sambung samping. 
Sedangkan perhitungan hubungan aksesibilitas informasi berdasarkan jumlah sumber informasi yang dimanfaatkan dengan persepsi petani kakao terhadap tahapan teknik sambung samping diperoleh nilai dari koefisien korelasi Rank

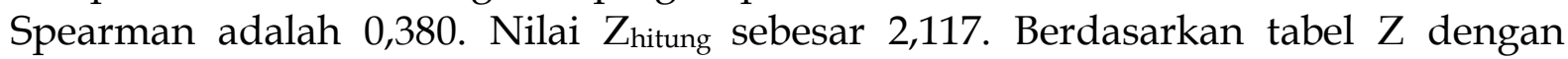
menggunakan a 0,05 maka diperoleh $Z_{\text {tabel }}$ sebesar 1,96. Dapat dilihat bahwa $Z_{\text {hitung }}>$ Ztabel dengan demikian $\mathrm{H}_{0}$ ditolak dan $\mathrm{H}_{1}$ diterima, artinya ada hubungan antara jumlah sumber informasi yang dimanfaatkan dengan persepsi petani kakao terhadap tahapan teknik sambung samping.

Hubungan Lingkungan Sosial dengan Persepsi Petani Kakao Terhadap Tahapan Teknik Sambung Samping

Berdasarkan hasil penelitian dapat diketahui bahwa nilai dari koefisien korelasi

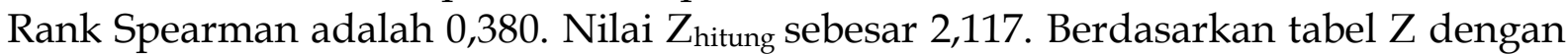
menggunakan a 0,05 maka diperoleh $Z_{\text {tabel }}$ sebesar 1,96. Dapat dilihat bahwa $Z_{\text {hitung }}>$ $Z_{\text {tabel }}$ dengan demikian $\mathrm{H}_{0}$ ditolak dan $\mathrm{H}_{1}$ diterima, artinya ada hubungan antara lingkungan sosial dengan persepsi petani kakao terhadap tahapan teknik sambung samping.

\section{Hubungan Faktor Pembentuk Persepsi dengan Persepsi Petani Kakao Terhadap Hasil Teknik Sambung Samping}

Faktor pembentuk persepsi yang diteliti meliputi umur, pendidikan formal, pendidikan non formal, pengalaman berusahatani, aksesibilitas terhadap informasi dan lingkungan sosial. Persepsi petani kakao terhadap hasil teknik sambung samping terdiri dari tiga parameter yaitu persepsi terhadap produksi tanaman kakao sambung samping, kualitas tanaman kakao sambung samping, keuntungan secara ekonomi tanaman kakao sambung samping. Adapun untuk melihat ada tidaknya hubungan antara faktor pembentuk persepsi dengan persepsi petani kakao terhadap hasil teknik sambung samping dapat dilihat pada penjelasan berikut.

\section{Hubungan Umur dengan Persepsi Petani Kakao Terhadap Hasil Teknik Sambung Samping}

Berdasarkan hasil penelitian dapat diketahui bahwa nilai dari koefisien korelasi Rank Spearman adalah 0,209. Nilai Z hitung sebesar 1,582. Berdasarkan tabel Z dengan menggunakan a 0,05 maka diperoleh $Z_{\text {tabel }}$ sebesar 1,96. Dapat dilihat bahwa Zhitung $<$ Ztabel dengan demikian $\mathrm{H}_{0}$ diterima dan $\mathrm{H}_{1}$ ditolak, artinya tidak ada hubungan antara umur dengan persepsi petani kakao terhadap hasil teknik sambung samping.

Hubungan Pendidikan Formal dengan Persepsi Petani Kakao Terhadap Hasil Teknik Sambung Samping

Berdasarkan hasil penelitian dapat diketahui bahwa nilai dari koefisien korelasi Rank Spearman adalah -0,020. Nilai Z hitung sebesar -0,111. Berdasarkan tabel Z dengan menggunakan a 0,05 maka diperoleh $Z_{\text {tabel }}$ sebesar 1,96. Dapat dilihat bahwa Zhitung $<Z_{\text {tabel }}$ dengan demikian $\mathrm{H}_{0}$ diterima dan $\mathrm{H}_{1}$ ditolak, artinya tidak ada hubungan antara pendidikan formal dengan persepsi petani kakao terhadap hasil teknik sambung samping. 
Hubungan Pendidikan Non Formal dengan Persepsi Petani Kakao Terhadap Hasil Teknik Sambung Samping

Berdasarkan hasil penelitian dapat diketahui bahwa nilai dari koefisien korelasi Rank Spearman adalah 0,363. Nilai Z hitung sebesar 2,022. Berdasarkan tabel Z dengan menggunakan a 0,05 maka diperoleh $Z_{\text {tabel }}$ sebesar 1,96. Dapat dilihat bahwa Zhitung $>$ $Z_{\text {tabel }}$ dengan demikian $\mathrm{H}_{0}$ ditolak dan $\mathrm{H}_{1}$ diterima, artinya ada hubungan antara pendidikan non formal dengan persepsi petani kakao terhadap hasil teknik sambung samping.

Hubungan Pengalaman Berusahatani dengan Persepsi Petani Kakao Terhadap Hasil Teknik Sambung Samping

Berdasarkan hasil penelitian dapat diketahui bahwa nilai dari koefisien korelasi Rank Spearmant adalah 0,249. Nilai Z $Z_{\text {hitung }}$ sebesar 1,387. Berdasarkan tabel Z dengan menggunakan a 0,05 maka diperoleh $Z_{\text {tabel }}$ sebesar 1,96. Dapat dilihat bahwa Zhitung < $Z_{\text {tabel }}$ dengan demikian $\mathrm{H}_{0}$ diterima dan $\mathrm{H}_{1}$ ditolak, artinya tidak ada hubungan antara pengalaman berusahatani dengan persepsi petani kakao terhadap hasil teknik sambung samping.

Hubungan Aksesibilitas Informasi dengan Persepsi Petani Kakao Terhadap Hasil Teknik Sambung Samping

Aksesibilitas terhadap informasi merupakan pencarian informasi yang dilakukan responden dengan mengikuti kegiatan penyuluhan dalam setahun, kemauan mendapatkan informasi dan jumlah sumber informasi yang aktif dimanfaatkan responden terhadap informasi yang berkaitan dengan tanaman kakao.

Hasil perhitungan hubungan aksesibilitas informasi berdasarkan frekuensi pencarian informasi dengan persepsi petani kakao terhadap hasil teknik sambung samping diperoleh nilai dari koefisien korelasi Rank Spearman adalah 0,163. Nilai

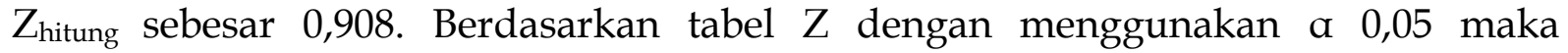
diperoleh $Z_{\text {tabel }}$ sebesar 1,96. Dapat dilihat bahwa $Z_{\text {hitung }}<Z_{\text {tabel }}$ dengan demikian $\mathrm{H}_{0}$ diterima dan $\mathrm{H}_{1}$ ditolak, artinya tidak ada hubungan antara frekuensi pencarian infromasi dengan persepsi petani kakao terhadap hasil teknik sambung samping.

Hasil perhitungan hubungan aksesibilitas informasi berdasarkan kemauan responden mendapatkan informasi dengan persepsi petani kakao terhadap hasil teknik sambung diperoleh nilai dari koefisien korelasi Rank Spearman adalah 0,163.

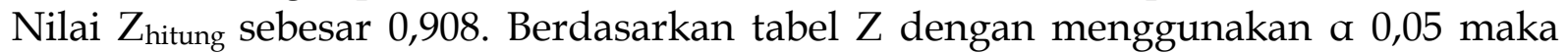
diperoleh $Z_{\text {tabel }}$ sebesar 1,96. Dapat dilihat bahwa $Z_{\text {hitung }}<Z_{\text {tabel }}$ dengan demikian $\mathrm{H}_{0}$ diterima dan $\mathrm{H}_{1}$ ditolak, artinya tidak ada hubungan antara frekuensi pencarian infromasi dengan persepsi petani kakao terhadap hasil teknik sambung samping.

Hasil perhitungan hubungan aksesibilitas informasi berdasarkan jumlah sumber informasi yang dimanfaatkan dengan persepsi petani kakao terhadap hasil teknik sambung samping diperoleh nilai dari koefisien korelasi Rank Spearman adalah 0,102. Nilai $Z$ hitung sebesar 0,568. Berdasarkan tabel $Z$ dengan menggunakan a 0,05 maka diperoleh $Z_{\text {tabel }}$ sebesar 1,96. Dapat dilihat bahwa $Z_{\text {hitung }}<z_{\text {tabel }}$ dengan demikian $\mathrm{H}_{0}$ diterima dan $\mathrm{H}_{1}$ ditolak, artinya tidak ada hubungan antara jumlah sumber informasi yang dimanfaatkan dengan persepsi petani kakao terhadap hasil teknik sambung samping. 
Hubungan Lingkungan Sosial dengan Persepsi Petani Kakao Terhadap Hasil Teknik Sambung Samping

Berdasarkan hasil penelitian dapat diketahui bahwa nilai dari koefisien korelasi Rank Spearman adalah 0,033. Nilai Z hitung sebesar 0,184. Berdasarkan tabel Z dengan menggunakan a 0,05 maka diperoleh $Z_{\text {tabel }}$ sebesar 1,96. Dapat dilihat bahwa Zhitung $<z_{\text {tabel }}$ dengan demikian $\mathrm{H}_{0}$ diterima dan $\mathrm{H}_{1}$ ditolak, artinya tidak ada hubungan antara lingkungan sosial dengan persepsi petani kakao terhadap hasil teknik sambung samping.

\section{Kesimpulan}

Total persepsi petani kakao terhadap tahapan teknik sambung samping yang meliputi persepsi terhadap penyiapan batang bawah, pengayatan batang bawah, penyiapan entres, penyisipan entres, ketinggian sambungan, penyungkupan entres, pengamatan sambungan, serta pemeliharaan sambungan dikategorikan sangat baik (skor 4,48), sedangkan total persepsi petani kakao terhadap hasil teknik sambung samping yang meliputi produksi, kualitas tanaman kakao, dan keuntungan usahatani dikategorikan sangat baik (skor 4,23). Hasil penelitian ini menunjukkan terdapat hubungan antara pendidikan non formal dalam hal ini keikutsertaan penyuluhan dan pelatihan penyambungan, aksesibilitas terhadap informasi dalam hal ini frekuensi pencarian informasi, kemauan mendapatkan informasi, jumlah sumber informasi yang dimanfaatkan, dan juga terdapat hubungan pada lingkungan sosial dengan persepsi petani kakao terhadap tahapan teknik sambung samping. Terdapat hubungan antara pendidikan non formal terhadap hasil teknik sambung samping.

\section{Daftar Pustaka}

Anggraini, M. S., 2011. Persepsi Petani Terhadap Pengembangan Komoditas Garut (Maranta Aurindinacea L) Di Kecamatan Polokarto Kabupaten Sukoharjo. (Skripsi) Universitas Sebelas Maret: Surakarta.

Arikunto, S.,. 2010. Prosedur Penelitian Suatu Pendekatan Praktik. Rineka Cipta: Jakarta.

BPS, 2015. Produksi Perkebunan Menurut Provinsi dan Jenis Tanaman. http://www.bps.go.id. Diakses pada tanggal 19 Oktober 2015: Makassar.

BPS Provinsi Sulawesi Selatan. 2015. Luas Areal dan Produksi Tanaman Perkebunan Menurut Kabupaten/Kota Provinsi Sulawesi Selatan. http://sulsel.bps.go.id. Diakses pada tanggal 19 Oktober 2015: Makassar.

Damayanti, W., 2010. Persepsi Petani Terhadap Budidaya Wijen Di Kabupaten Sukoharjo. (Skripsi) Universitas Sebelas Maret: Surakarta.

Fahmid, I.M., 2013. Social Innovation Among Ethnics in Cocoa Farming at Sulawesi, Indonesia. Journal of Biology, Vol.3, No.11.

Firdaus, 2015. Teknologi Sambung Samping dapat Meningkatkan Produktivitas Kakao Petani di Provinsi Aceh. http://nad.litbang.pertanian.go.id. Diakses pada tanggal 6 April 2015: Makassar. 
Hariani, E. B., 2013. Persepsi Petani Terhadap Program Gerakan Peningkatan Produksi Pangan Berbasis Korporasi (GP3K) di Desa Jati Kecamatan Jaten Kabupaten Karanganyar. (Skripsi). Universitas Sebelas Maret: Surakarta.

Husna, N., M.S.S. Ali, D. Salman, P. Hijjang, F. Djufry, A.A. Amrawaty, 2015. Merging Indigeneous Knowledge and Modern Knowledge in Agricultural Development. IJAS, Vol.2, No., 2.

Manubelu, Y. S.. 2011. Pengaruh Jenis Klon dan Lama Penyimpanan Entres Terhadap Pertumbuhan Sambung Samping Kakao (Theobroma Cacao L.). http://www.pps.unud.ac.id. Diakses pada tanggal 6 April 2015: Makassar.

Nai, E., 2013. Rehabilitasi Kakao dengan Metode Sambung Samping. http://nad.litbang.pertanian.go.id. Diakses pada tanggal 6 April 2015: Makassar.

Novitasari, A., 2013. Persepsi Petani Terhadap Padi Varietas Situ Bagendit Di Kecamatan Delanggu Kabupaten Klaten. (Skripsi). Universitas Sebelas Maret: Surakarta

Prasetyo, K. P., 2013. Persepsi Petani Terhadap Kemitraan Sayuran Dengan Asosiasi Aspakusa Makmur Kabupaten Boyolali. (Skripsi) Universitas Sebelas Maret: Surakarta

Prawoto, A.A., et-al., 2008. Panduan Lengkap Kakao Manajemen Agribisnis dari Hulu hingga Hilir. Penebar Swadaya: Depok

Pusat Penenlitian Kopi dan Kakao Indonesia, 2010. Buku Pintar Budidaya Kakao. Agro Media Pustaka: Jakarta Selatan.

Safaruddin. 2013. Studi Kelayakan Budidaya Tanaman Kakao Sambung Samping. http://journal.uncp.ac.id. Diakses pada tanggal 15 Oktober 2015: Makassar.

Salman, D., 2016. Sosiologi Desa: Revolusi Senyap dan Tarian Kompleksitas. Makassar: Ininnawa.

Samadi. 2006. Geografi 2.Yudhistira: Bogor

Sihombing, R. B., 2008. Peranan Pengendalian Internal Dalam Menunjang Efektivitas Penjualan Perusahaan. (Skripsi) Universitas Widyatama: Bandung.

Siregar, S., 2015. Statistika untuk Penelitian Dilengkapi Perhitungan Manual dan Aplikasi SPSS Versi 17. Rajawali Pers: Jakarta.

Soekartawi, 1988. Prinsip Dasar Komunikasi Pertanian Teori dan Aplikasi. Rajawali Press: Jakarta.

Sugiyono, 2015. Statistika untuk Penelitian. Alfabeta: Bandung.

Wahyuniarti, I., 2011. Persepsi Petani Terhadap Bahan Pangan Organik Di Desa Sukorejo Kecamatan Sambirejo Kabupaten Sragen. (Skripsi). Universitas Sebelas Maret: Surakarta.

Wardhani, P. W., 2008. Hubungan Nilai Budaya Uncertainty Avoidance dengan Tingkah Laku Inovatif. http://lib.ui.ac.id. Diakses pada tanggal 19 Oktober 2015: Makassar.

Yatman, H. N., 2011. Persepsi Petani Terhadap Water Resources and Irrigation Sector Management Program di Kecamatan Jatipurno Kabupaten Wonogiri. (Skripsi). Universitas Sebelas Maret: Surakarta. 